\title{
Ovarian steroid involvement in endogenous opioid modulation of LH secretion in seasonally anoestrous mature ewes*
}

\author{
A. N. Brooks $\uparrow$, N. B. Haynes, K. Yang and G. E. Lamming \\ AFRC Research Group on Hormones and Farm Animal Reproduction, University of Nottingham, \\ Faculty of Agricultural Science, Sutton Bonington, Loughborough, Leics LE12 SRD, U.K.
}

\begin{abstract}
Summary. In June, 16 mature ewes were ovariectomized and allocated to four groups: 1, saline; 2, naloxone; 3, progesterone implant plus naloxone; 4, oestrogen implant plus naloxone. Steroids were implanted at the time of ovariectomy. At 5 days after ovariectomy, the animals were intravenously infused with saline for $8 \mathrm{~h}$ and naloxone $(50 \mathrm{mg} / \mathrm{h})$ in saline for $8 \mathrm{~h}$ the following day. Three intact ewes were given naloxone in a similar way. During infusions and for $8 \mathrm{~h}$ on the day after naloxone, jugular venous blood samples were taken every $15 \mathrm{~min}$ and assayed for $\mathrm{LH}$.

Naloxone resulted in significant increases in mean LH concentration $(P<0.01)$, LH episode frequency and episode height $(P<0.05)$ in Group 3 ewes, but was without effect in any other group. These results provide evidence that the progesterone status of the ewe affects its response to naloxone, that progesterone negative feedback on $\mathrm{LH}$ release may be mediated by an opioid system, and that increased oestradiol negative feedback during seasonal anoestrus is unlikely to work via increased opioid inhibition of $\mathrm{LH}$.
\end{abstract}

\section{Introduction}

The opiate antagonist naloxone will stimulate LH secretion during the reproductive cycle of mature ewes, suggesting that endogenous opioids may be involved in the mechanisms modulating this hormone, although naloxone did not alter $\mathrm{LH}$ secretion in mature ewes during seasonal anoestrus (Brooks, Lamming, Lees \& Haynes, 1986). These results suggested that an adequate steroid milieu is required, in particular an elevated concentration of progesterone, for opioids to be effective in mature ewes. Evidence for steroid involvement in the opioid control of gonadotrophin secretion in other species is compelling. For instance, in humans, naloxone is capable of stimulating LH secretion only during the late follicular and luteal phases of the menstrual cycle, when circulating ovarian steroid concentrations are high (Quigley \& Yen, 1980). After gonadectomy in rats, opiates and naloxone lose their ability to affect LH secretion, a situation which is reversed by steroid hormone replacement therapy (Bhanot \& Wilkinson, 1984; Petraglia et al., 1984).

During seasonal anoestrus in ewes, plasma $\mathrm{LH}$ values are depressed as a result of an increase in the sensitivity of the hypothalamo-pituitary axis to the negative feedback effects of oestrogen. The consequent lack of gonadotrophin secretion ensures that no normal ovulatory cycles occur, and because of this, progesterone is lacking (Yuthasastrakosol, Palmer \& Howland, 1973; Legan, Karsch \& Foster, 1977). 
The present experiments were designed (a) to study the effects of ovariectomy during the nonbreeding season to see whether naloxone is able to enhance LH secretion in the absence of the influences of the powerful negative-feedback effects of oestradiol, and (b) to monitor the LH response to naloxone when ovariectomized ewes were treated with oestradiol or progesterone.

\section{Materials and Methods}

Experimental design. Nineteen mature Cheviot ewes weighing between 50 and $58 \mathrm{~kg}$ were used in June 1984. All ewes had given birth to lambs during the previous spring and were kept at pasture, the lambs being removed 2 weeks before the start of the experiment. Sixteen of the ewes were then ovariectomized using aseptic procedures under pentobarbitone-induced anaesthesia sustained with halothane and nitrous oxide mixture. The ovariectomized ewes were allocated to four equal groups: Group 1, saline; Group 2, naloxone treatment; Group 3, progesterone implants and naloxone treatment; Group 4, oestradiol implants and naloxone treatment. The 3 intact animals served as a naloxone treatment control group (Group 5).

Steroid implants were inserted subcutaneously in the axillary region behind the front leg at the time of ovariectomy. Two progesterone implants each containing $375 \mathrm{mg}$ progesterone in a siliconeelastomer matrix (Sil-Estrus: Ceva, Paris, France) were inserted into Group 3. Oestrogen implants were made according to the method of Karsch et al. (1973) using Silastic tubing of internal diameter $3.5 \mathrm{~mm}$, external diameter $6 \mathrm{~mm}$, and length $50 \mathrm{~mm}$ (code no. 116050, Esco rubber) and oestradiol-17 $\beta$ (Sigma Chemicals, Poole, Dorset, U.K.). One implant calculated to produce plasma oestradiol-17 $\beta$ levels of $3-5 \mathrm{pg} / \mathrm{ml}$ (W. Haresign, personal communication) was inserted into each ewe in Group 4. To minimize a peak of oestradiol release upon insertion, the implants were soaked in sterile water overnight and then in $70 \%$ alcohol for $30 \mathrm{~min}$ before use.

After ovariectomy the ewes were transferred into indoor pens each containing 3 animals. Whilst inside, conditions of natural daylength were maintained and a diet of hay, conventional sheep ration and water was made available. At 4 days after ovariectomy both jugular veins on each sheep were fitted with venous cannulae using a local anaesthetic and sterile procedures, one to be used for taking blood samples and the other for infusions, which were carried out using portable syringe drivers (type MS16, Graseby Dynamics Ltd, Watford, Herts, U.K.) strapped to the back of the sheep. On Days 5 and 6 after ovariectomy an 8-h period of intravenous infusion was carried out in all sheep, starting at 09:00 h. On Day 5 all sheep received sterile saline $(0.9 \% \mathrm{w} / \mathrm{v}(2 \mathrm{ml} / \mathrm{h}))$. On Day 6 the ewes in Group 1 again received saline and those in all other groups were infused with naloxone (Sterling Winthrop, Guildford, Surrey, U.K.) in saline at a $50 \mathrm{mg}(\sim 1.0 \mathrm{mg} / \mathrm{kg}$ liveweight) dose $(2 \mathrm{ml}) / \mathrm{h}$. During these infusions and for a further $8 \mathrm{~h}$ starting at 09:00 h on Day 7, $3 \mathrm{ml}$ blood samples were taken at $15 \mathrm{~min}$ intervals for $\mathrm{LH}$ determinations. A daily blood sample was taken from the time of ovariectomy to the end of the experiment for progesterone determinations. All blood samples were immediately centrifuged and the plasma stored at $-15^{\circ} \mathrm{C}$ until required for assay.

Rationale for the experimental design used. In ewes the post-ovariectomy rise in LH secretion occurs rapidly within the first 5-10 days, the rise continuing at a slower rate for at least the next 50 days (Reeves, O’Donell \& Denorsica, 1972; Roche, Foster, Karsch, Cook \& Dziuk, 1970). When oestrogen is given as an implant at the time of ovariectomy in seasonally anoestrous ewes, plasma concentrations of $\mathrm{LH}$ remain basal throughout the non-breeding season (Legan et al., 1977). Progesterone administered in the same way only maintains basal LH values for about 6 days, and then a gradual rise in plasma LH concentration is observed (Karsch, Legan, Hauger \& Foster, 1977). It was therefore considered essential that treatment of ewes in Group 3 should occur no more than 6 days after ovariectomy since, if a greater length of time elapsed, there might be a gradual rise in $\mathrm{LH}$ which would mask any effects of naloxone. However, to be consistent, the sheep in Group 2 had to be treated at the same time, when LH values would still be rising as a result of 
ovariectomy. To reconcile this problem, Group 1 (ovariectomy + saline) was included, thus enabling treatment effects to be isolated by seeing whether any rise in $\mathrm{LH}$ secretion after naloxone was greater than the rise after saline. Group 4 was not a problem in this respect since oestradiol maintains low LH values for a considerable length of time after ovariectomy. Intact animals (Group 5) were included to confirm that naloxone did not affect LH secretion in these anoestrous sheep since the experimental conditions were different from those reported previously (Brooks $e t$ al., 1986).

Hormone assays. Plasma LH content was measured by the specific double-antibody radioimmunoassay as described by McLeod, Haresign \& Lamming (1982). Sensitivity, defined as 2 s.d. from the binding value at zero concentration of LH was $0.3 \mathrm{ng} \mathrm{NIH-LH-S23} \mathrm{equiv./ml} \mathrm{plasma.}$ Intra- and inter-assay coefficients of variation (CV) within this study were 15.2 and $5.9 \%$ respectively. Progesterone was measured by the method of Haresign, Foster, Haynes, Crighton \& Lamming (1975). The limit of sensitivity was $0.1 \mathrm{ng} / \mathrm{ml}$ plasma and intra- and inter-assay CV were $<12 \%$.

Statistical analysis. An LH episode was defined as a rise in plasma concentrations of the hormone greater than $50 \%$ above the preceding baseline value with at least two points between the peak value and the succeeding trough (the choice of $50 \%$ is arbitrary, but is more than $4 \times \mathrm{CV}$ for duplicate pairs in the assay). Differences in mean LH concentration and episode height between control and treatment periods were assessed by a split-plot analysis of variance and numbers of peaks by analysis of deviance (Nelder \& Wedderburn, 1972), as described previously (Brooks et al., 1986).

\section{Results}

Mean LH concentrations, episode frequency and episode heights are summarized in Fig. 1. For reasons not apparent to us, it was difficult to keep the blood sampling cannulae patent during this experiment, particularly in the later stages. This resulted in no data for 1 ewe in Group 3. Individual plasma LH profiles for the 3 remaining Group 3 sheep are shown in Fig. 2.

\section{Group 1}

The pulsatile pattern of LH secretion for these ewes was similar to that reported elsewhere, episodes occurring at a frequency of around one every 1-2h (Diekman \& Malven, 1973; Davis \& Borger, 1974). There were no differences between control, treatment and run-off periods. Mean LH concentration during the control period was significantly elevated $(P<0.05)$ above the same period in the Group 5 sheep $(9 \cdot 8 \pm 1.8$ and $4.6 \pm 0.7 \mathrm{ng} / \mathrm{ml}$, respectively; Fig. 1). There was a tendency for LH concentrations to increase, as expected, between control, treatment and run-off periods and the increase in episode height between control and run-off periods was significant $(P<0 \cdot 01)$.

\section{Group 2}

LH concentration during the control period was lower than that of Group 1 ewes, although episode frequency was similar (Fig. 1). There was an increase in mean LH concentrations from $5.87 \pm 1.4$ to $7.98 \pm 2.4 \mathrm{ng} / \mathrm{ml}$ and in episode height from $11.61 \pm 2.7$ to $16.25 \pm 4.2 \mathrm{ng}$ between the control and naloxone treatment periods. These values fell to $6.0 \pm 1.8 \mathrm{ng} / \mathrm{ml}$ and $13 \pm 4 \mathrm{ng}$ respectively during the run-off period. There was considerable variability between animals and none of these differences was significant. 

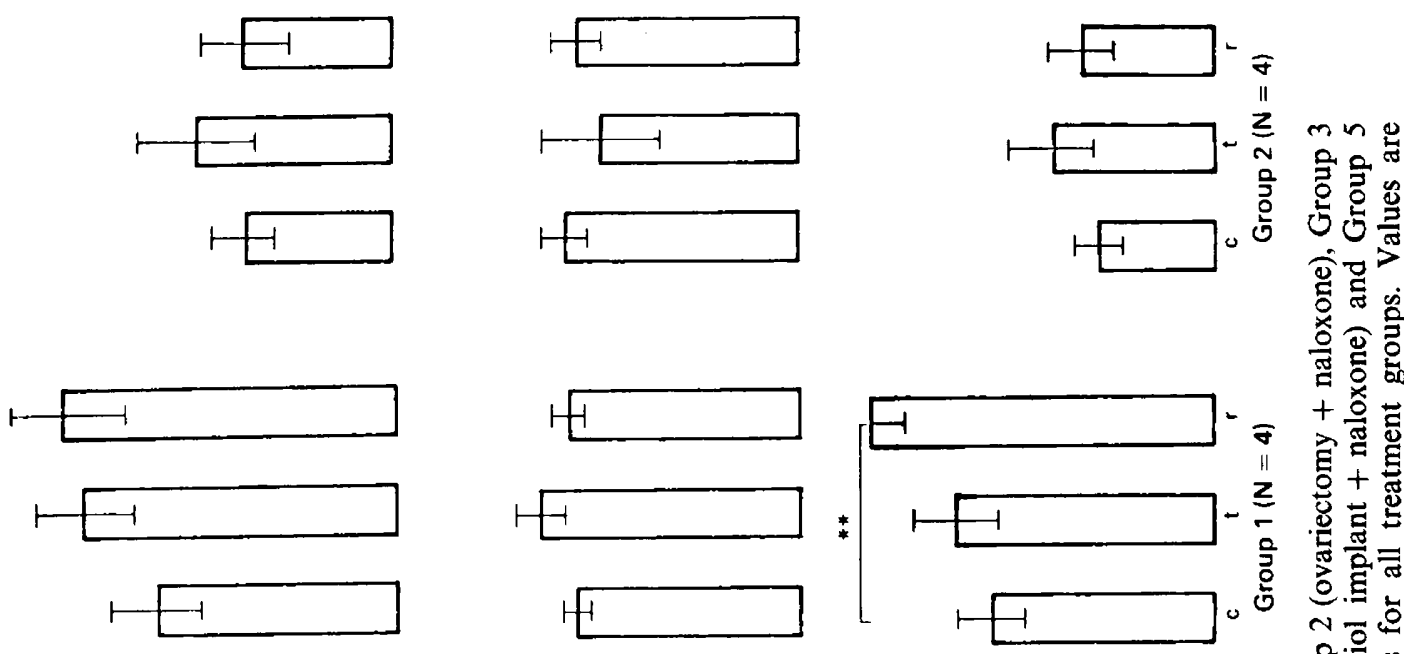

음ำ
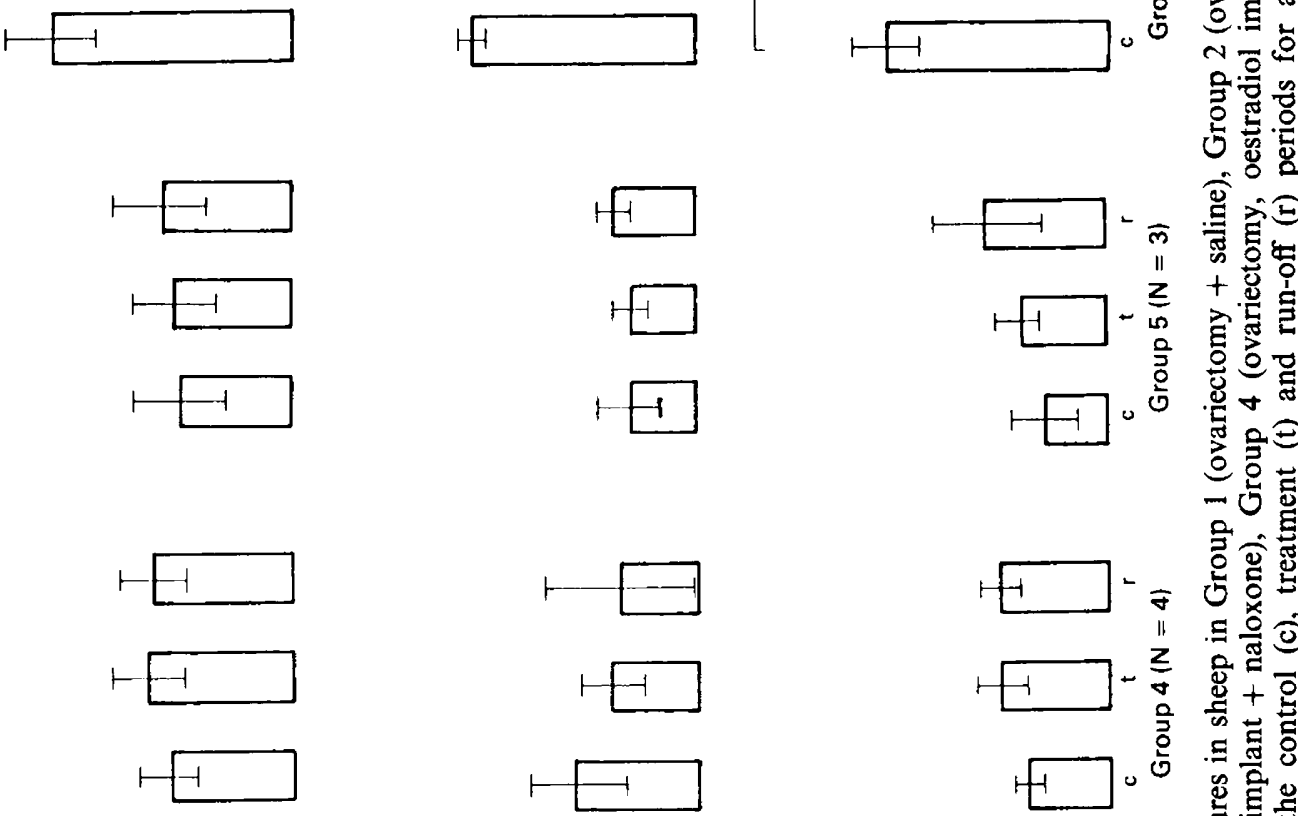

จิ요

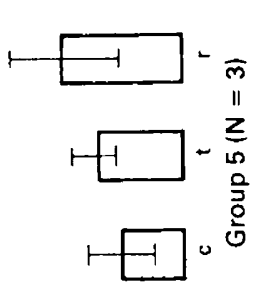

需

+ 岁定 V



है

政

잉

o

- 0
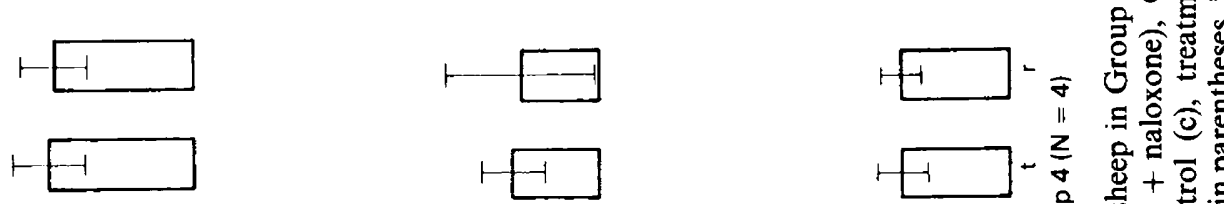

1.. 웅

원영
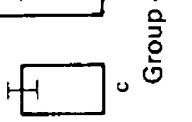

क

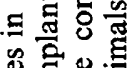

․ㅡㄹ.

要

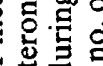
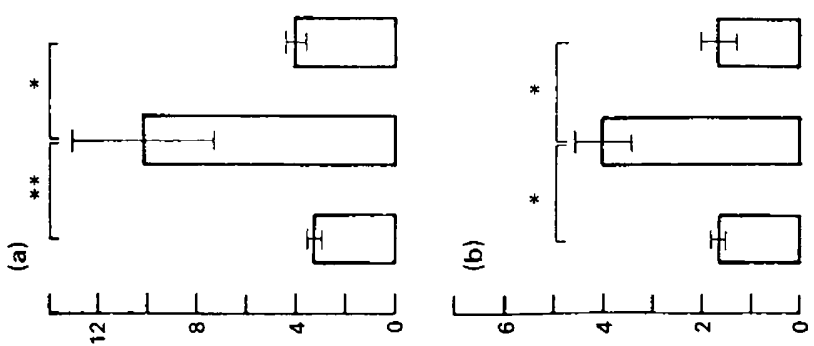

(|w/6u) '040ว Hา

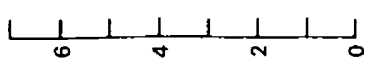

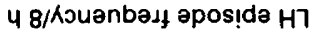

Ð0

$4 \frac{1}{8} 1 \frac{1}{2}+\frac{1}{2} 1-$

(ןw/6u) әрnџ!|due әроs!də Hา 

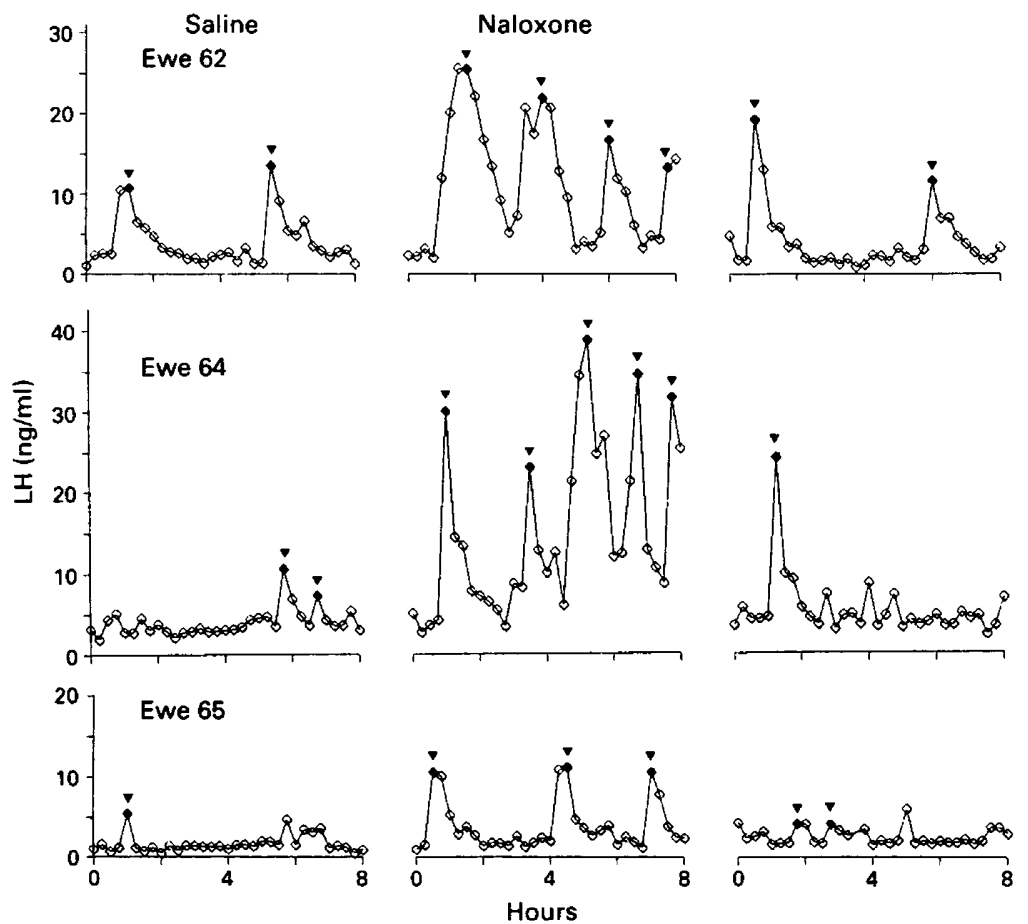

Fig. 2. Plasma LH concentrations in 3 ewes, which were ovariectomized, implanted with progesterone and subsequently treated with naloxone (Group 3). LH episodes confirming to the definition used (see text) are indicated by $\boldsymbol{\nabla}$.

\section{Group 3}

During the control period mean LH concentrations, episode frequency and peak heights were significantly $(P<0.05)$ lower than those in ewes in Group 1 (Fig. 1). Naloxone treatment induced a significant $(P<0.01)$ increase in mean LH concentration from $3.26 \pm 0.76$ to $10.20 \pm 3.24 \mathrm{ng} / \mathrm{ml}$, due to a significant increase $(P<0.05)$ in both episode frequency and episode height (Fig. 2). Mean LH concentration and episode frequency returned to pretreatment values in the run-off period and were significantly lower $(P<0.05)$ than in the naloxone treatment period. Episode height was also diminished in the run-off period, but not significantly so.

\section{Group 4}

During the control period, all measures of LH secretion were significantly lower $(P<0.05)$ than those in Group 1 and were similar to those in Group 3 (Fig. 1). LH secretion was unaffected by naloxone treatment.

\section{Group 5}

The results were similar to those of Group 4 sheep, and again LH secretion was not affected by naloxone infusion.

\section{Progesterone concentrations}

Progesterone concentrations were undetectable in all except the ewes in Group 3, in which mean 
values were $1.84 \pm 0.83,0.98 \pm 0.46$ and $1.04 \pm 0.48 \mathrm{ng} / \mathrm{ml}$ during the control, treatment and run-off period respectively.

\section{Discussion}

In this study naloxone was only effective in enhancing LH secretion in the ewes which were ovariectomized and implanted with progesterone. Ovariectomized control or oestradiol-17 $\beta$-implanted ewes and intact animals failed to respond. Therefore, progesterone negative feedback upon LH secretion may be mediated at least in part via opioid-containing neurones but oestrogen negative feedback in the anoestrous ewe probably works through a different mechanism.

For a number of species it has been suggested that oestrogen/progesterone combinations elicit optimum responses of $\mathrm{LH}$ to naloxone. For instance in the human the best $\mathrm{LH}$ response to naloxone is found during the mid-luteal phase of the menstrual cycle, when both oestrogen and progesterone concentrations are elevated (Snowden, Khan-Dawood \& Dawood, 1984; Quigley \& Yen, 1980) and a combination of oestrogen and progesterone given to ovariectomized monkeys elicits the largest increases in hypophysial portal blood $\beta$-endorphin concentrations (Wardlaw, Wehrenberg, Ferin, Autunes \& Frantz, 1982). In the ovariectomized rat, injection of a combination of oestradiol benzoate and progesterone, or oestradiol benzoate alone reduced serum LH values and this inhibition was reversed by naloxone (Van Vugt, Sylvester, Aylsworth \& Meites, 1982). In addition, it has been reported that post-menopausal or oophorectomized women do not show an LH response to naloxone, a situation which is reversed if naloxone therapy is preceded by pretreatment with a progestagen or in a combination of progestagen and oestrogens (Casper \& AlapinRubillovitz, 1985; Shoupe, Montz \& Lobo, 1985). When ewes are implanted with progesterone immediately after ovariectomy the post-ovariectomy rise in LH is prevented, an effect which lasts for some 6-8 days before a gradual rise takes place to levels between those observed in intact and ovariectomized ewes. In long-term ovariectomized ewes the ability of progesterone to suppress LH secretion is slight unless the ewes are pretreated with oestrogen (Karsch et al., 1977). The high response to progesterone in the short-term ovariectomized ewe is thought to be a result of synergism with residual oestrogenic effects which only slowly disappear, resulting in the gradual increase in LH (Martin, 1984). The progesterone-treated ewes in the current study could therefore be considered to be 'oestrogen primed'.

It has previously been shown that naloxone was ineffective in stimulating LH secretion in ovariectomized oestradiol-implanted ewes kept under artificial long days (Jackson \& Schillo, 1983), an observation in accord with the findings reported here, but those workers also demonstrated a significant stimulation of $\mathrm{LH}$ concentration and increase in episode frequency in unimplanted ovariectomized ewes. A very large dose of naloxone (4-fold that used in the present paper) has also been shown to enhance LH pulse frequency in castrated rams (Schanbacher, 1982). The results of the current study are at variance with these reports but it should be borne in mind that the design differs from that of Jackson \& Schillo (1983) in that our experiments were carried out at 6 days rather than 3 months after ovariectomy. They also agree with studies in the rat in which it has been demonstrated that after ovariectomy there was a rapid decline in the ability of naloxone to stimulate and the opioid agonist FK33-824 to inhibit LH release (Bhanot \& Wilkinson, 1983). Castrated male hamsters implanted with testosterone showed a marked increase in LH secretion when treated with naloxone during a long photoperiod (which stimulates reproductive activity in this species) but not during a short photoperiod. In these animals, therefore, there seems to be a photoperiodically-induced change in the ability of naloxone to induce $\mathrm{LH}$ release which is not dependent upon changes in circulating steroid concentations (Roberts, Hastings, Martensz \& Herbert, 1985). On the face of it, this differs from the situation in the ewe, and it would be of interest to carry out an equivalent experiment on ovariectomized steroid-treated ewes during the breeding season.

The present experiments do not give any information on the precise mechanisms by which progesterone and opioids interact together to modulate LH secretion. However, it has been postulated, 
on the basis of data obtained in the rat, that there may be an axo-axonic link between endogenous opioid peptide and adrenergic systems governing the control of pulsatile GnRH released which is influenced by gonadal steroid feedback (Kalra \& Kalra, 1984). It is possible, on the basis of the present results, that such a mechanism involving the GnRH pulse generator may also be operational in the ewe and this is an aspect of further study.

We thank Dr R Carter of Sterling Winthrop for the supply of naloxone; the Agricultural and Food Research Council for financial support; NIH for LH; and Dr W. Haresign for surgically preparing the sheep. A.N.B. was in receipt of a University of Nottingham postgraduate scholarship.

\section{References}

Bhanot, R. \& Wilkinson, M. (1983) Opiatergic control of $\mathrm{LH}$ secretion is eliminated by gonadectomy. Endocrinology 112, 399-401.

Bhanot, R. \& Wilkinson, M. (1984) The inhibiting effect of opiates on gonadotrophin secretion is dependent upon gonadal steroids. J. Endocr. 102, 133-141.

Brooks, A.N., Lamming, G.E., Lees, P.D. \& Haynes, N.B. (1986) Opioid modulation of LH secretion in the ewe. J. Reprod. Fert. 76, 693-708.

Casper, R.F. \& Alapin-Rubillovitz, S. (1985) Progestins increase endogenous opioid peptide activity in postmenopausal women. J, clin. Endocr. Metab. 60, 34-36.

Davis, S.L. \& Borger, M.L. (1974) Dynamic changes in plasma prolactin, luteinizing hormone and growth hormone in ovariectomized ewes. J. Anim. Sci. 38, $715-802$.

Diekman, M.A. \& Malven, P.V. (1973) Effect of ovariectomy and estradiol on LH patterns in ewes. $J$. Anim. Sci. 37, 562-567.

Haresign, W., Foster, J.P., Haynes, N.B., Crighton, D.B. \& Lamming, G.E. (1975) Progesterone levels following treatment of seasonally anoestrous ewes with synthetic LH-releasing hormone. J. Reprod. Fert. 43, $269-279$.

Jackson, G.L. \& Schillo, K.K. (1983) Naloxone stimulates secretion of luteinizing hormone in ovariectomized ewes. Biol. Reprod. 28, Suppl. 1, 97, Abstr.

Kalra, S.P. \& Kalra, P.S. (1984) Opioid-adrenergicsteroid connection in regulation of luteinizing hormone secretion in the rat. Neuroendocrinology 38, $418-426$.

Karsch, F.J., Dierschke, D.J., Weick, R.F., Yamaji, T., Hotchkiss, J. \& Knobil, E. (1973) Positive and negative feedback control by estrogen of luteinizing hormone secretion in the Rhesus monkey. Endocrinology 92, 799-804.

Karsch, F.J., Legan, S.J., Hauger, R.L. \& Foster, D.L. (1977) Negative feedback action of progesterone on tonic luteinizing hormone secretion in the ewe: Dependence on ovaries. Endocrinology 101, 800-806.

Legan, S.J., Karsch, F.J. \& Foster, D.L. (1977) The endocrine control of seasonal reproductive function in the ewe: A marked change in response to the negative feedback action of oestradiol on luteinizing hormone secretion. Endocrinology 101, 818-824.

Martin, G.B. (1984) Factors affecting the secretion of luteinizing hormone in the ewe. Biol. Rev. 59, 1-87.

McLeod, B.J., Haresign, W. \& Lamming, G.E. (1982)
The induction of ovulation and luteal function in seasonally anoestrous ewes treated with small-dose multiple injections of GnRH. J. Reprod. Fert. 65, 215-221.

Nelder, J.A. \& Wedderburn, R.W.M. (1972) Generalized linear models. Jl R. Statist. Soc. A 135, 370-384.

Petraglia, F., Locatelli, V., Penalva, A., Cocchi, D., Genazzani, A.R. \& Muller, E.E. (1984) Gonadal steroid modulation of naloxone-induced LH secretion in the rat. J. Endocr. 101, 33-39.

Quigley, M.E. \& Yen, S.S.C. (1980) The role of endogenous opiates on LH secretion during the menstrual cycle. J. clin. Endocr. Metab. 51, 179-181.

Reeves, J.J., O'Donell, D.A. \& Denorsica, F. (1972) Effect of ovariectomy on serum luteinizing hormone (LH) concentrations in the anoestrous ewe. J. Anim. Sci. 35, 73-78.

Roberts, A.C., Hastings, M.H., Martensz, N.D. \& Herbert, J. (1985) Naloxone-induced secretion of LH in the male Syrian hamster: modulation by photoperiod and gonadal steroids. J. Endocr. 106, 243-248.

Roche, J.F., Foster, D.L., Karsch, F.J., Cook, B. \& Dziuk, P.J. (1970) Levels of luteinizing hormone in sera and pituitaries of ewes during the estrous cycle and anestrus. Endocrinology 86, 568-572.

Schanbacher, B.D. (1982) Naloxone provoked LH release in rams, wethers and wethers implanted with testosterone. J. Androl. 3, 41-42, Abstr. 97.

Shoupe, D., Montz, F.J. \& Lobo, R.A. (1985) The effects of estrogen and progestin on endogenous opioid activity in oophorectomized women. J, clin. Endocr. Metab. 60, 178-183.

Snowden, E.V., Khan-Dawood, F. \& Dawood, M. (1984) The effect of naloxone on endogenous opioid regulation of pituitary gonadotrophins and prolactin during the menstrual cycle. J. clin. Endocr. Metab. 59, 298-302.

Van Vugt, D.A., Sylvester, P.W., Aylsworth, C.F. \& Meites, J. (1982) Counteraction of gonadal steroid inhibition of luteinizing hormone release by naloxone. Neuroendocrinology 34, 274-278.

Wardlaw, S.L., Wehrenberg, W.B., Ferin, M., Autunes, J.L. \& Frantz, A.G. (1982) Effect of sex steroids on $\beta$-endorphin in hypophyseal portal blood. $J$. clin. Endocr. Metab. 55, 877-881.

Yuthasastrakosol, P., Palmer, W.M. \& Howland, D.E. (1973) Hormone levels in the anestrus and cycling ewe. J. Anim. Sci. 37, 334.

Received 24 July 1985 